\title{
KLAUZULA SPOŁECZEŃSTWA DEMOKRATYCZNEGO (OBYWATELSKIEGO) W ZBIOROWYM PRAWIE PRACY
}

\author{
Abstract \\ Democratic (civil) society clause in the collective labour law
}

Resolving any social conflicts, including collective labour disputes, requires preservation of human dignity, having regard to vital interests of the State being its citizen's community. Therefore, social conflicts are to be resolved in a responsible way. This is reflected in a responsible society clause embracing an imperative of reasonableness and decency as well.

Słowa kluczowe: spór zbiorowy, klauzula odpowiedzialności, wspólnota, godność

Keywords: collective dispute, liability clause, community, dignity

ASCJ: 3308, JEL: K 31

\section{Wstęp}

Od zakończenia II wojny światowej bardzo silnie rozwija się, w szczególności w tzw. państwach demokracji zachodniej, idea praw człowieka. Akcentuje się, że idea ta obejmuje zarówno przestrzeń polityczną, społeczną, kulturową, jak i w szczególności prawną. Na fundamentach konstrukcyjnych tej idei zostały mianowicie oparte podstawy funkcjonowania państwa, prawa, kultury czy społeczeństwa demokracji zachodniej. Wyrazem jej są także regulacje międzynarodowego prawa publicznego, co na gruncie prawa pracy odnosić się będzie do praw pracowniczych. Od strony aksjologicznej na pierwszym miejscu jest eksponowana godność człowieka. Godność człowieka jest bowiem nie jednym z wielu praw, a podstawą wszystkich praw (Działocha 2010). Jest wartością normatywną, gdyż na jej podstawie można kierować określone roszczenia i powoływać się na nią przed sądem. Jednakże godność człowieka nie jest prawem podmiotowym uzyskanym w wyniku przyjęcia określonej normy $w$ akcie prawnym, lecz prawem naturalnym. Jest bowiem przyrodzonym i niezbywalnym prawem człowieka, co oznacza, że jest nienaruszalna i niezależna od władzy państwowej, a tym samym nie może jej żadna władza regulować. 
Zauważalne jest to także w wymiarze aksjologiczno-filozoficznym, gdzie uznano, że godność jest fundamentem (źródłem) wolności i prawa (Oniszczuk 2010). Godności przyznaje się mianowicie bezwzględną niewzruszalność, a w konsekwencji nieograniczoność, co oznacza, że jest niezależna od władzy państwowej, a tym samym nie może jej żadna władza regulować. $Z$ tego też względu na władze publiczne nakłada się obowiązek jej poszanowania i ochrony (Działocha 2010). Przysługuje każdemu i jest niestopniowana (Jedlecka 2013). Stanowi fundament konstrukcyjny, na którym winna być zbudowana idea wolności i praw człowieka oraz obywatela w państwie, co w świecie kultury, filozofii i prawa w umownym ujęciu śródziemnoatlantyckim stało się właśnie elementem praw człowieka. Koncepcja ta legła u podstaw rozwoju współczesnej nauki praw człowieka. Godność jest zatem uniwersalną zasadą, która opiera się na moralnych wartościach adresatów norm prawnych (Dworkin, za: Biśta 2010). Z tego też względu, jak wspomniano, jest uwzględniana przez instrumenty międzynarodowego prawa publicznego, które odnoszą się do sfery praw pracowniczych. Godność pracownika stała się bowiem obecnie prawem tak samo uniwersalnym, jak prawo do życia, zdrowia, zabezpieczenia socjalnego, nietykalności cielesnej (zakaz molestowania seksualnego) czy prywatności (Szewczyk 2007; Świątkowski 2011; Dörre-Nowak 1999-2000; Dörre-Nowak 2004, 2005, 2006; Wujczyk 2012; Żołyński 2018), jak również prawem do oporu pracowników przeciwko niesprawiedliwości w zakresie szeroko rozumianego zatrudnienia. Zachowanie godności w miejscu pracy jest tak samo ważne, jak pozyskiwanie środków finansowych na życie poprzez świadczenie pracy.

Szczególnej uwagi wymaga okoliczność, że godność pracownika, będąca dobrem osobistym człowieka, podobnie jak inne dobra osobiste jest pojęciem integralnym i przysługuje zatrudnionemu jako osobie w ogóle. Prawo do godności człowieka ${ }^{1}$ jest podstawowym prawem moralnym, zasadą etyczną, obejmującą wartości, które człowiek uznaje za nadrzędne wobec innych wartości i które wynikają z prawa naturalnego. Jest ono afirmacją godności osobowej; szacunkiem dla autonomii człowieka. $Z$ tego względu jest także „podstawową determinantą państwa i prawa” oraz zagadnieniem interdyscyplinarnym (Sadowski 2007). Powoduje to, że w literaturze z zakresu prawa konstytucyjnego godność pojmowana jest jako centralna kategoria systemu prawnego, co oznacza, że jednostka ludzka wyróżniona jest jako najważniejsza i wzorcowa wartość wobec innych wartości. Jest ona nierozerwalna i związana z każdą istotą ludzką (Complak 2006).

Przedstawienie w zarysie powyższej wartości (tj. godności) jest niezmiernie ważne w przedmiocie analizowania klauzuli społeczeństwa demokratycznego w zbiorowym

${ }^{1}$ Godność człowieka jest pojęciem wieloznacznym. Generalnie można wyróżnić jej dwie postacie: godność osobową i godność osobistą. Godność osobowa oznacza godność ludzką, godność człowieka. Przysługuje ona przez sam fakt bycia człowiekiem i jego „uprzywilejowania” w świecie przyrody. Określa się ją mianem godności przyrodzonej lub człowieczeństwa. Oznacza to, że przysługuje ona bezwzględnie każdemu człowiekowi - po prostu dlatego że jest człowiekiem. Z kolei godność osobista jest to cecha osobowa, która wyraża się w poczuciu własnej wartości, a zatem w oczekiwaniu szacunku ze strony innych. 
prawie pracy². W szczególności dotyczy to przypadku akcji protestacyjnej załogi, będącej konsekwencją zaistnienia sporu zbiorowego pracy. Przestrzeganie godności pracownika jest mianowicie determinantą wszelkich relacji w stosunkach pracy. Jest zatem także determinantą powodzenia procesu rozwiązywania sporu zbiorowego. Brak szacunku ze strony pracodawcy wobec pracowników (i vice versa) uniemożliwia mianowicie polubowne rozwiązanie zaistniałego konfliktu, bez względu na jego przyczyny, tj. czy podstawą sporu są warunki pracy i płacy, czy inne okoliczności.

\section{Pojęcie klauzuli społeczeństwa demokratycznego w zbiorowym prawie pracy}

Współczesny świat, co jest już truizmem, ma wymiar ze wszech miar globalny. Obecne społeczeństwa nie funkcjonują w próżni i w oderwaniu od innych uwarunkowań - ani społeczno-polityczno-gospodarczych, ani prawnych. Globalizacja rozwiązań czy idei prawnych w szczególności widoczna jest w skali jednokulturowej, jaką jest szeroko rozumiana zachodnia kultura chrześcijańska. Uniformizacja prawa widoczna jest w takich jednolitych społecznie jednostkach organizacyjnych jak federacja amerykańska (USA) czy Unia Europejska, oczywiście przy występowaniu pewnych odmienności, nazwijmy to - regionalnych (własne prawo stanowe w USA czy odrębne prawa poszczególnych państw Unii Europejskiej). Uniformizacja niezbędna jest także wewnątrz każdej, nawet małej wspólnoty. $Z$ tego też względu praw i wolności nie można traktować jak bytu absolutnego. Uznaje się bowiem, że w pewnych okolicznościach prawa i wolności mogą zostać ograniczone, co oznacza, iż zasadnym jest formułowanie, oczywiście w umownym znaczeniu, klauzuli rozsądku (odpowiedzialności) społecznej, klauzuli społeczeństwa demokratycznego (obywatelskiego) w zbiorowym prawie pracy.

W warstwie konstrukcyjnej klauzula społeczeństwa demokratycznego jest wyrazem legalizmu, gdyż społeczeństwo demokratyczne szanuje obowiązujące prawo i daje temu wyraz poprzez jego przestrzeganie. Jest zatem wyrazem przeciwwagi dla anarchizacji prawa i obowiązującego porządku konstytucyjnego, a zatem stanowi kontrę dla anarchizacji państwa. Zabrania ona wszczynania sporów zbiorowych i w konsekwencji strajków, wtedy gdy prawo takich akcji nie dopuszcza. Co więcej, klauzula ta wręcz wymusza uznanie, że strajk ma charakter ultima ratio i nie powinien być przeprowadzony, a wszczęty - winien być odwołany, gdy zagraża on szczególnie istotnym interesom pracodawcy, państwa czy społeczeństwa.

Okolicznościami takimi mogą być:

(1) Interesy pracodawcy. Zagadnienie to jest bardzo szerokie i z tego względu skomplikowane. Niemniej w świetle dyrektywy wynikającej z art. 17 ust. 3 ustawy o rozwiązywaniu sporów zbiorowych (Dz.U. 2019, poz. 174 tekst jedn. ze zm, dalej: „,ustawa

${ }^{2}$ Szczególnie ważne jest w zbiorowym prawie pracy, gdyż w swojej istocie jest ono najbardziej indywidualną częścią prawa pracy. Ostatecznie bowiem beneficjentami regulacji zbiorowego prawa pracy stają się pracownicy (Sobczyk 2014). 
o rozwiązywaniu sporów zbiorowych) strajkujący winni „wyważyć” korzyści i straty wynikające ze strajku. W tym przepisie wskazano mianowicie, że przy podejmowaniu decyzji o ogłoszeniu strajku podmiot reprezentujący interesy pracowników powinien wziąć pod uwagę współmierność żądań do strat związanych ze strajkiem. Jest to zatem zasada współmierności żądań do strat, w literaturze określana jest mianem adekwatności socjalnej (Żołyński 2012, wraz z przyw. literaturą). Zasada ta jest wyrazem moralności publicznej i zawiera w sobie dyrektywę ustawodawczą (Masewicz 1993).

Jedynym kryterium „współmierności” nie może być porównanie wyrażonej w pieniądzu ogólnej sumy żądań strajkujących do wysokości spodziewanych strat wywołanych strajkiem, gdyż „współmierność” odnosi się także do aspektów pozamaterialnych, społecznych (Masewicz 1994, s. 180).

Przy podejmowaniu decyzji o ogłoszeniu strajku organizatorzy tej akcji powinni zatem przeanalizować wszystkie „za” i „przeciw”, a w szczególności to, jakie koszty (straty) związane ze strajkiem może ponieść pracodawca. Powinni wziąć także pod uwagę koszty, jakie wynikną dla samych pracowników (na przykład utrata wynagrodzenia). Z tego też względu strajk nie może być ogłoszony jedynie po to, aby wyrządzić pracodawcy szkody, które w przyszłości uniemożliwią normalne funkcjonowanie zakładu (przykładowo w kopalni wstrzymany zostanie proces odwodnienia szybów czy w hucie zostanie całkowicie wygaszona praca w piecach hutniczych). Zasada adekwatności socjalnej oznacza, że strajk jest niedopuszczalny, jeżeli straty wyrządzone tą akcją przewyższałyby realne korzyści objęte rewindykacją pracowników. Obowiązek swoiście rozumianej lojalności wobec pracodawcy, przejawiający się przestrzeganiu zasady socjalnej adekwatności, podyktowany jest też względami ogólnospołecznymi. Ocena socjalnej adekwatności strajku należy nie tylko do związku, ale również do załogi głosującej za lub przeciw proklamowaniu strajku.

(2) Interesy państwa (Żołyński 2013b, wraz z przyw. literaturą). Prawo do strajku lub innej akcji protestacyjnej nie jest jednak prawem bezwzględnym, przysługującym pracownikom wobec wszystkich pracodawców i w każdej sytuacji. W cywilizowanym państwie zawsze mogą bowiem zaistnieć sytuacje, których ziszczenie się wpływa bezpośrednio na szeroko rozumiane prawa pracownicze. Okoliczności te powodują, że prawa te są albo ograniczane, albo zawieszane, gdyż realizacja ich prowadziłaby do chaosu, anarchii lub niewymiernych strat materialnych i niematerialnych. Odnośnie do prawa do strajku lub innej akcji protestacyjnej - z reguły dotyczy to szczególnie ważnego interesu państwa. Nie wynika to, niestety, wprost z ustawy o rozwiązywaniu sporów zbiorowych, co de lege ferenda winno być objęte stosowną nowelizacją, poprzez choćby odwołanie do innych regulacji prawnych. Na gruncie prawa polskiego uprawnienie do przejściowej „reglamentacji” tych akcji protestacyjnych pracowników wynika z innych aktów prawnych, rangi ustawowej, które dotyczą stanu wojennego, stanu wyjątkowego oraz stanu klęski żywiołowej. Aktami tymi są mianowicie:

a) ustawa $z$ dn. 29 sierpnia 2002 r. o stanie wojennym oraz o kompetencjach Naczelnego Dowództwa Sił Zbrojnych i zasadach jego podległości konstytucyjnym organom Rzeczpospolitej Polskiej (Dz.U. 2017, poz. 1932 tekst jedn. ze zm.). Zgodnie 
$\mathrm{z}$ art. 19 ust. 1 tej ustawy można zawiesić prawo do strajku i innych form protestacyjnych w odniesieniu do określonych kategorii pracowników lub w określonych dziedzinach. Realizacja tego uprawnienia następuje na mocy rozporządzenia Prezydenta RP wydanego $\mathrm{w}$ trybie art. 3 wspomnianej ustawy;

b) ustawa z dn. 21 czerwca 2002 r. o stanie wyjątkowym (Dz.U. 2017, poz. 1928 tekst jedn. ze zm.) - art. 16 ust. 1 pkt 3 i 4 uprawniają do wprowadzenia możliwości zawieszenia strajków pracowniczych i innych form protestu w odniesieniu do określonych kategorii pracowników lub w określonych dziedzinach, a także strajków i innych niż strajki form akcji protestacyjnych rolników;

c) ustawa z dnia 18 października 2002 r. o stanie klęski żywiołowej (Dz.U. 2017, poz. 1897 tekst jedn. ze zm.) - art. 21 ust. 1 pkt 17 mówi o możliwości wprowadzenia zakazu prowadzenia strajku w odniesieniu do określonych kategorii pracowników lub w określonych dziedzinach.

Na podstawie powyższych ustaw strajk:

- nie powinien być w ogóle ogłoszony,

- strajk ogłoszony nie powinien być rozpoczęty,

- strajk rozpoczęty winien być niezwłocznie zakończony.

(3) Interesy społeczeństwa (Żołyński 2013b). Wymóg uwzględnienia interesów społeczeństwa dotyczyć może różnych szczególnych okoliczności. Stąd problem jest w istocie bardzo złożony, gdyż dotyczy to takich sytuacji, gdy przerwanie pracy może spowodować oczywiste i bezpośrednie zagrożenie. Będzie to uzależnione od czasu, zakresu i miejsca przeprowadzonej akcji. Z tego też względu, na przykład w sytuacji ekstremalnych i długotrwałych upałów w okresie letnim, nie powinien być ogłaszany strajk na określonych stanowiskach pracy w zakładach oczyszczania miast i wywozu nieczystości, gdyż może to doprowadzić do zagrożenia epidemiologicznego. Z kolei w przypadku ogłoszenia klęski żywiołowej strajk nie może zostać ogłoszony w jednostkach, które mają obowiązek usuwania zagrożenia życia ludzkiego (na przykład w wyniku powodzi, obfitych opadów śniegu itp.). Identycznie sytuacja będzie się przedstawiała w podmiotach zaopatrujących w wodę, energię elektryczną i odbiór ścieków. Strajk nie może zostać przeprowadzony na instalacjach i urządzeniach chemicznych, których bezpieczne wyłączenie będzie wymagało dłuższego czasu.

Szczególne znaczenie ma to w szeroko rozumianej służbie zdrowia. Problem prawa pracowników służby zdrowia do strajku był już w literaturze prawa pracy przedmiotem szerszej analizy (Żołyński 2013b, wraz z przyw. literaturą). Ujawniły się w nim diametralnie różne stanowiska, od całkowitego zakazu prawa do strajku pracowników służby zdrowia, na przykład lekarzy, przez uznanie za nielegalny strajku w tych placówkach, które sprawują „bezpośrednią” opiekę medyczną, a więc zakazanie prawa uczestnictwa w strajku tylko w razie wątpliwości dotyczących prawdopodobieństwa wystąpienia zagrożenia dla życia i zdrowia pacjentów, po stanowiska dopuszczające strajk, jednak z wyraźnym wyłączeniem określonych miejsc czy stanowisk. Rozpatrując zatem niniejszy problem ze względu na przedmiotowy charakter ograniczenia prawa do strajku, należy uznać, że zakaz ten powoduje niejasną sytuację sprowadzającą się do faktu, że tylko 
niektórzy z pracowników zakładu pracy pozbawieni są prawa do strajku. Z tego też względu za słuszny należy uznać pogląd, że wśród personelu służby zdrowia znajdują się stanowiska, na których zaprzestanie pracy może spowodować zagrożenia dla życia lub zdrowia, lecz stwierdzenie, iż wszyscy lekarze są objęci zakazem strajku, jest zbyt daleko idące. Niewykonywanie bowiem pracy przez personel lekarski niewątpliwie powoduje utrudnienia w korzystaniu z usług przez pacjentów i może stwarzać poważne uciążliwości dla społeczeństwa, ale niekoniecznie musi zagrażać ich życiu lub zdrowiu. Zagrożenie dla życia i zdrowia występuje bezpośrednio niewątpliwie tam, gdzie wymagane jest natychmiastowe udzielenie pomocy (tzw. oddziały OIOM, ratownictwa medycznego, intensywnej terapii, pogotowie ratunkowe), lecz są i takie jednostki organizacyjne służby zdrowia, gdzie strajk, w ścisłym tego słowa znaczeniu, bezpośredniego zagrożenia nie wywołuje (rejestracje chorych, poradnie przyszpitalne, rehabilitacje itp.).

Na gruncie prawa polskiego klauzulę społeczeństwa demokratycznego w zbiorowym prawie pracy należy w szczególności wyprowadzić z regulacji zawartych w ustawie o rozwiązywaniu sporów zbiorowych. Przepisy tego aktu prawnego wprost odnoszą się do maksymy nihil novi sine communi consensu („nic nowego bez zgody ogółu”). W szczególności jest to widoczne w instytucji tzw. referendum strajkowego. Otóż związki zawodowe autonomicznie, a więc bez upoważnienia udzielonego im przez inne podmioty, w tym w szczególności bez zgody załogi zakładu pracy, mogą wszcząć i prowadzić spór zbiorowy z pracodawcą. Posiadają mianowicie wprost taką legitymację w ustawie o rozwiązywaniu sporów zbiorowych, a pośrednio w ustawie z dn. 23 maja 1991 r. o związkach zawodowych (Dz.U. 2019, poz. 263 tekst jedn. ze zm., dalej: „u.z.z."), $\mathrm{z}$ uwagi na unormowania wskazujące, że związek zawodowy reprezentuje oraz broni praw, interesów zawodowych i socjalnych ludzi pracy (art. 1 ust. 1 u.z.z.). Jednakże jego zmaterializowanie się w postaci strajku wymaga już zgody załogi zarówno co do samej możliwości ogłoszenia strajku, jak też co do aktywności pracownika w tej formie protestu. Załoga zakładu pracy wyraża swoją odpowiedzialność poprzez opowiedzenie się co do strajku, jak również poprzez faktyczny czas jego trwania. Może bowiem w każdym momencie cofnąć swoją zgodę na aktywny udział w proteście poprzez złożenie oświadczenia pracodawcy w każdym czasie o powrocie do pracy. Tym samym - de facto, choć nie de iure - może doprowadzić do zakończenia sporu zbiorowego. Zatem maksyma nihil novi sine communi consensu winna być rozumiana nie jako wyraz anarchizacji, lecz jako wyraz odpowiedzialności obywatelskiej; w skali zakładu pracy odpowiedzialności za losy podmiotu, w którym są zatrudnieni, a pośrednio za losy swoich rodzin czy społeczności co najmniej lokalnej.

W polskim zbiorowym prawie pracy w aspekcie rozwiązywania sporów zbiorowych klauzuli tej należy poszukiwać także poprzez analogię do rozwiązań przyjętych w publicznym międzynarodowym prawie. Otóż klauzula ta została wyrażona art. 29 ust. 1 i 2 Powszechnej deklaracji praw człowieka (przyjęta na III Sesji Zgromadzenia Ogólnego ONZ w Paryżu w dn. 10 grudnia 1948 r.; Dz.U. 1948, nr 43, poz. 308) i sprowadza się do uznania, że „[k]ażdy człowiek ma obowiązki wobec społeczeństwa, bez którego niemożliwy jest swobodny i pełny rozwój jego osobowości". Niemniej: 
W korzystaniu ze swych praw i wolności każdy człowiek podlega jedynie takim ograniczeniom, które są ustalone przez prawo wyłącznie w celu zapewnienia odpowiedniego uznania i poszanowania praw i wolności innych i w celu uczynienia zadość słusznym wymogom moralności, porządku publicznego i powszechnego dobrobytu demokratycznego społeczeństwa ${ }^{3}$.

Klauzula społeczeństwa demokratycznego znajduje również wyraźne zakotwiczenie w obowiązującej w Polsce konstytucyjnej zasadzie demokratycznego państwa prawnego. Zasada ta jest bowiem fundamentem, na którym opiera się ustawodawstwo, wykładnia oraz proces stosowania prawa. Wyrażona w art. 2 Konstytucji (Dz.U. 1997, nr 78, poz. 483 ze zm.) stwierdza, że „Rzeczpospolita Polska jest demokratycznym państwem prawnym, urzeczywistniającym zasady sprawiedliwości społecznej”. Trybunał Konstytucyjny, stwierdzając, że dana regulacja jest niezgodna z Konstytucją, wielokrotnie zarzuca zaskarżanym przepisom naruszenie właśnie tej zasady. Stąd odwołując się do niej, należy wyjaśnić pojęcia w niej zawarte. Otóż pojęcie „państwo prawne” w znaczeniu formalnym rozumiane jest jako przestrzeganie prawa przez wszystkich jego adresatów (bez wyjątku), zarówno przez obywateli, jak i przez organy państwowe. Na gruncie prawa pracy będzie to w szczególności oznaczało pełne respektowanie regulacji zarówno publiczno-prawnych, jak i prywatno-prawnych (na przykład porozumień zbiorowych) przez pracodawców oraz partnerów społecznych (związki zawodowe czy rady pracowników). Z treści szeregu orzeczeń Trybunału Konstytucyjnego można wyprowadzić mianowicie także wniosek, że nieodłącznym elementem demokratycznego państwa prawa jest szeroko rozumiana przyzwoitość. Przyzwoitość w zbiorowym prawie pracy będzie oznaczała, że żadna ze stron nie może być dominująca, a więc obie strony są równe. Będzie to więc wyrazem szeroko rozumianej zasady ochrony zaufania obywateli do państwa, poprzez między innymi zapewnienie jednostce oraz określonej grupie szeroko rozumianego bezpieczeństwa prawnego. Umożliwia jej zatem decydowanie o własnym postępowaniu w oparciu o pełną znajomość przesłanek działania organów

${ }^{3} \mathrm{~W}$ tym też względzie przykładowo można wskazać, że funkcjonują w praktyce restrykcje w zakresie swobody koalicji funkcjonariuszy państwowych, które najczęściej sprowadzają się do ograniczeń $\mathrm{w}$ wyborze reprezentujących ich organizacji związkowych. $Z$ reguły rozwiązania legislacyjne ograniczają możliwość zrzeszania się wyłącznie w związku zawodowym danej kategorii pracowników, np. w związku zawodowym policjantów (tzw. zasada monizmu związkowego). Jak zauważa Komitetu Ekspertów do Spraw Stosowania Konwencji i Zaleceń MOP, wprowadzenie takiego wyłączenia ma na celu zapobieżenie wszelkim formom politycznego zaangażowania się przez członków związku sektora publicznego lub wręcz „odstraszania” ich przed podejmowaniem akcji strajkowych. Zdaniem MOP, zasada monizmu dopuszczalna jest jedynie w odniesieniu do organizacji najniższego szczebla oraz przy zastrzeżeniu, że organizacje te: nie są ograniczone do pracowników poszczególnego ministerstwa, departamentu czy służby oraz mogą przystępować do wybranych przez siebie federacji i konfederacji na zasadach obowiązujących pracowników sektora prywatnego. Za niedopuszczalny uznano jednakże wymóg obligatoryjnego zakładania różnych organizacji związkowych dla każdej kategorii urzędników publicznych. Jednocześnie MOP wyraźnie uznaje, że w świetle Konwencji nr 87 (Dz.U. 1958, nr 29, poz. 125) możliwość zrzeszania się w związkach zawodowych przez osoby zatrudnione w administracji publicznej w żaden sposób nie przesądza kwestii ich prawa do strajku (Sękara 2008, s. 49-50). 
państwowych oraz konsekwencji prawnych poszczególnych zachowań i zdarzeń (m.in. wyrok TK z 25 czerwca 2002 r., K 45/01, Dz.U. 2002, poz. 923). W ogólności chodzi o to, aby prawo było pewne, a jego konsekwencje przewidywalne. Wiąże się z tym konieczność jednolitego stosowania prawa w stosunku do takich samych spraw. Gdzie nie ma sprawiedliwych zasad, reguł postępowania, nie ma prawa sprawiedliwego.

Przepis art. 2 Konstytucji, formułujący zasadę demokratycznego państwa prawnego, nie poprzestaje jednak na określeniu, że RP jest takim państwem, stwierdza bowiem dodatkowo, że państwo ma „urzeczywistniać zasady sprawiedliwości społecznej”. Sprawiedliwość społeczna jest klauzulą generalną, przez którą należy rozumieć, że: (1) stanowi odesłanie do kwestii aksjologicznych, a więc wartości, które winny być chronione; (2) ogranicza arbitralność podejmowania konkretnych decyzji przez podmioty uprawnione do ich podejmowania.

Ani prawo, ani żadna idea nie mogą funkcjonować bez określonych fundamentów. Stąd klauzuli społeczeństwa demokratycznego należy poszukiwać, odwołując się do zagadnień aksjologiczno-filozoficznych oraz doktryn polityczno-prawnych. Otóż w zakresie aksjologiczno-filozoficznym, a także politycznym, uwzględniając wymogi społeczne, wywodzić ją można z tzw. reguły Radbrucha ${ }^{4}$. W dużym uproszczeniu - znamienny dla treści przekazanych przez Gustawa Radbrucha poglądów stał się następujący wywód (m.in. Żołyński 2016, s. 64-79):

Konflikt między sprawiedliwością i bezpieczeństwem prawnym należałoby rozwiązać w ten sposób, ażeby prawo pozytywne zagwarantowane przez ustawodawstwo i władzę państwową miało pierwszeństwo również wtedy, gdy treściowo jest niesprawiedliwe i niecelowe chyba, że sprzeczność z ustawy pozytywnej ze sprawiedliwością osiąga taki stopień, że ustawa jako prawo niesprawiedliwe powinna ustąpić sprawiedliwości.

Stanowisko to utożsamiane jest z łacińską paremią Lex iniusta non est lex - „prawo niesłuszne nie jest prawem” - której autorem jest św. Augustyn. W ujęciu Gustawa Radbrucha ta paremia powinna zaś otrzymać brzmienie: Lex iniustissima non est lex, czyli „prawo rażąco niesłuszne nie jest prawem”. Jednak jest to tylko ogólna orientacja, ponieważ formuła składa się z trzech elementów, które mają postać osobnych tez. Każda z nich stanowi osobny fragment koncepcji, która jako całość nie posiada homogenicznego charakteru. Pierwsza z tez nazywana jest „tezą o rażącej sprzeczności” (Unertraglichkeitsthese). Ma ona postać twierdzenia, że prawo, które jest w rażącym stopniu sprzeczne z zasadami sprawiedliwości, nie może być stosowane. Radbruch, formułując tę tezę, podkreśla: „Jedno musi utknąć w świadomości prawników: mogą istnieć ustawy o takim stopniu niesprawiedliwości i szkodliwości, że należy odmówić im charakteru prawa" (Żołyński 2016, s. 79). Formuła Radbrucha nakazuje zatem nieprzestrzeganie prawa pozytywnego, jeśli narusza ono podstawowe normy moralne. Jako przykład można

${ }^{4}$ Gustaw Radbruch, niemiecki filozof i profesor prawa. Trzykrotny minister sprawiedliwości w tzw. Republice Weimarskiej. 
podać orzecznictwo podczas procesu norymberskiego, kiedy państwo nazistowskie nakazywało łamać wiele norm moralnych, a wśród nich podstawowe - prawo do życia. Inaczej ujmując, formuła ta sprowadza się do tego, że jeśli norma prawna w drastyczny sposób łamie podstawowe normy moralne, to nie obowiązuje. Taka norma nie dostępuje godności bycia prawem, może być odrzucona i tym samym obywatele nie mają obowiązku jej przestrzegania, a administracja państwowa i sądownictwo - jej stosowania. Reguła Gustawa Radbrucha będzie odgrywała zatem szczególną rolę przy podejmowaniu decyzji o ogłoszeniu strajku generalnego, powszechnego, skierowanego de facto przeciwko organom państwa, w przypadku wprowadzania prawa łamiącego podstawowe reguły praworządności przyjęte w cywilizowanym świecie prawnej kultury Zachodu (o czym w dalszej części opracowania).

\section{Istota klauzuli społeczeństwa demokratycznego}

Klauzula społeczeństwa demokratycznego ma w istocie rzeczy największe znaczenie w sferze zbiorowego prawa pracy, choć oczywistym jest, że odnosi się także do innych gałęzi prawa, jak na przykład prawa konstytucyjnego. Stąd klauzula ta formułowana jest siłą rzeczy przez prawo publiczne, a więc prawo ustanawiane przez organa państwa, które to prawo na mocy woli partnerów społecznych w zbiorowym prawie pracy nie może być znoszone. Należy jednakże zwrócić wyraźnie uwagę na powinności ciążące na przyjętych przez państwo regulacjach mających na celu zabezpieczenie szeroko rozumianego bezpieczeństwa i porządku publicznego.

Po pierwsze procedury prawne związane ze wszczęciem sporu zbiorowego i następnie poprzedzające ewentualne ogłoszenie strajku nie mogą być skomplikowane, gdyż praktycznie uniemożliwiałyby wszczęcie sporu i ogłoszenie ostatniego jego etapu (tj. strajku) (MBP 2012, nr 548). W tym też względzie należy uznać, że także procedury o charakterze prywatno-prawnym, a więc wprowadzane na zasadzie consensusu pomiędzy stronami sporu, mające na celu „doprecyzowanie” regulacji ustanawianych przez podmioty legislacyjne państwa, także nie mogą być sprzeczne z wolnościową ideą sporu zbiorowego i akcji protestacyjnych. Nie mogą zatem tak uszczegóławiać regulacji o charakterze powszechnym, które by stały w kontrze do prawa do strajku. Stąd, regulacje prawa międzynarodowego w pełni uznają prawa pracowników i pracodawców wynikające z wolności związkowej, zwłaszcza w zakresie możliwości zawierania układów i porozumień zbiorowych do samodzielnego załatwiania sporów zbiorowych. Stwarza to gwarancje prawidłowej i lepszej ochrony prawnej w zbiorowych stosunkach pracy. Ustanowienie bowiem norm bezpośrednio przez reprezentację pracowników i pracodawcę w układach lub stosownych porozumieniach zbiorowych jest wyrazem kompromisu, odpowiadającego ich rzeczywistym oczekiwaniom i interesom. W konsekwencji, takie normy są przez partnerów społecznych chętniej respektowane, niż normy narzucone odgórnie przez ustawodawcę, z tego też względu są bardziej skuteczne w kształtowaniu podstaw trwałego ładu prawnego i pokoju społecznego w stosunkach pracy. Dostosowują 
bowiem zbiorowe prawo pracy do społecznej gospodarki rynkowej, a zatem harmonizuja je z jej wymogami. Zbiorowe prawo pracy jest mianowicie w swojej istocie najbardziej indywidualną częścią prawa pracy ${ }^{5}$. W ostateczności bowiem $w$ wyniku tych regulacji beneficjentami ich stają się poszczególni pracownicy (Sobczyk 2014).

Wstępnym, lecz istotnym warunkiem pokojowego przeprowadzenia procesu rozwiązywania sporu zbiorowego jest właściwy przepływ informacjí. Można zatem uznać, że jest to warunek sine qua non nie tylko procesu rokowań prowadzonego przez same strony sporu, lecz i powodzenia procesu mediacji, a więc włączenie się w proces rozwiązywania sporu zbiorowego niejako podmiotu trzeciego. Stwarza mianowicie podstawowy klimat do prowadzenia konstruktywnych rozmów między partnerami społecznymi i umożliwia właściwe zaangażowanie osoby trzeciej w rozwiązywanie zaistniałego konfliktu, jakim jest mediator. Informacja wpisuje się bowiem w aktywny nurt przeciwdziałania różnym formom eskalacji konfliktu. Stanowi w swojej istocie pewną formę dialogu społecznego, gdyż służy większej transparentności. Przyczynia się mianowicie do wzrostu zaufania pomiędzy stronami i zachowania pokoju społecznego, a tym samym do uniknięcia gwałtownych i nieprzemyślanych działań. Jest zatem skutecznym elementem skuteczności „zarządzania” procesem rozwiązywania sporu zbiorowego przez mediatora. Wiedza, zwłaszcza o kondycji finansowo-gospodarczej, umożliwia mediatorowi objaśnienia stronie pracowniczej charakteru stawianych żądań, ich realności, co nie pozostaje bez znaczenia dla sytuacji pracowników, która może powstać $\mathrm{w}$ wyniku zaistnienia strajku. Informacje będą zatem stanowily podstawę do ewentualnego zawarcia porozumienia, co $\mathrm{w}$ istocie stanowi zawarcie umowy pomiędzy partnerami społecznymi. Pozyskiwanie informacji w procesie mediacji podczas sporu zbiorowego w zakresie filozoficznym można określić mianem przechodzenia od koncepcji prawa pozytywistycznego do filozofii prawa jako umowy, a zatem rozwoju idei tzw. demokracji uczestniczącej (Maniewska 2007, s. 218; Machnikowska 2004, s. 99 i n.). Zakończenie sporu zbiorowego jest mianowicie szeroko rozumianą umową, umową społeczną, choć bazującą na prawie cywilnym, przy zachowaniu równości stron. Celem porozumienia się jest bowiem wypracowanie consensusu, co często przy faktycznym braku równości stron sporu zbiorowego jest utrudnione, a niejednokrotnie niemożliwe.

Dalej - klauzula społeczeństwa demokratycznego może, a nawet powinna w określonych stanach faktycznych być wyrażona poprzez prawo o charakterze prywatnym. Mam tutaj na myśli porozumienia zbiorowe zawierane pomiędzy pracodawcą a związkami zawodowymi o charakterze umownym. W porozumieniach tych organizacje związkowe wyrażałyby zgodę w zakresie czasowego wstrzymywania się od prowadzonych sporów zbiorowych. W szczególności strona społeczna, mając na uwadze potrzebę ochrony

${ }^{5}$ Przykładowo Trybunał Konstytucyjny uznał, że niektóre regulacje prawne zawierają luki prawne i wymagają wręcz pilnej zmiany przepisów (cyt. wyrok TK z 6 czerwca 2018 r., K 53/16, Dz.U. 2018, poz. 1149). Z tego też względu, z uwagi na fakt, że proces legislacyjny generalnie jest długotrwały, „poprawienie” regulacji ustawowej na korzyść pracowników może być dokonane $\mathrm{w}$ formie porozumienia zbiorowego.

${ }^{6}$ Podobnie Paweł Pettke, który stwierdza, że „istotą każdego dialogu jest przekazanie informacji, przedstawienie poglądów czy argumentów przez osoby w nim uczestniczące” (Pettke 2014, s. 420). 
pracodawcy z uwagi na uwarunkowania gospodarcze, a jednocześnie troskę o miejsca pracy, wyraża gotowość wzięcia na siebie ewentualnego niezadowolenia załogi z generalnie przyjętych warunków pracy i płac (Żołyński 2013a). Porozumienia takie stanowiłyby wyraz dojrzałości obywatelskiej, a zatem i rozsądku liderów związkowych kanalizujących i ostudzających wzburzenie pracowników.

W obowiązujących regulacjach wyraz odpowiedzialności społeczeństwa, którego na płaszczyźnie prawa pracy reprezentantem jest załoga zakładu pracy, stanowią mediacja i arbitraż. Instytucja mediacji (jak i zresztą arbitrażu) związana jest bowiem ściśle i nierozłącznie z nowoczesnym systemem rozwiązywania sporów zbiorowych w pracy. W tym też względzie należy zwrócić uwagę na regulacje Międzynarodowej Organizacji Pracy (dalej: „MOP”). Otóż standardy ustanowione przez MOP nakładają na partnerów społecznych wyczerpanie procedur pokojowego rozwiązania sporu zbiorowego. Pokojowy proces (zwany też irrenicznym) jest bowiem najlepszą drogą prowadzącą do porozumienia, a porozumienie jest najlepszym sposobem załatwienia sporu zbiorowego. Stąd funkcją procesu pokojowego jest w istocie próba godzenia wzajemnie sprzecznych interesów pracownika i pracodawcy, a więc godzenia interesów pracowników jako jednostki (co będzie domeną indywidualnego prawa pracy), a także godzenia interesów pracowników jako zbiorowości wobec pracodawcy (lub grupy pracodawców), co jest z kolei domeną zbiorowego prawa pracy. Sprzeczność ta wynika $\mathrm{z}$ faktu, że w cywilizowanym świecie podstawą funkcjonowania gospodarki jest idea „społecznej gospodarki rynkowej”. Godzenie wzajemnych sprzeczności nie jest sprawą prostą także $z$ uwagi na fakt, że zjawiska społeczne podlegające regulacjom prawa pracy mają charakter wybitnie dynamiczny i ciągle się zmieniają z uwagi na zaistniałą z reguły sytuację gospodarczą i społeczną. Okoliczności te spowodowały, że między innymi w tzw. zachodnich państwach Unii Europejskiej zrezygnowano ze skodyfikowania prawa pracy w postaci regulacji kodeksowej. Zamiast tego wprowadzono szereg odrębnych ustaw regulujących poszczególne instytucje z zakresu prawa pracy. W systemach zachodnich uznano ponadto, że wiele regulacji z zakresu prawa pracy winno mieć charakter elastyczny, a więc pozostawiono to unormowaniom z zakresu prawa układowego, co oznacza, że sprawy z zakresu akcji protestacyjnych mogą mieć w układach charakter obligacyjny. Prawo układowe ze swojej istoty jest bowiem bardziej elastyczne i podatne na dostosowanie się do zmieniającej się rzeczywistości społeczno-gospodarczej. Prawu temu łatwiej nadążać za rzeczywistością i wprowadzać normy prawne na korzyść pracowników, gdyż prawa pracy nie można kształtować w oderwaniu od środowiska pracowników reprezentowanych przez związki zawodowe i środowiska pracodawców reprezentowanych przez organizacje pracodawców. Stąd europejskie prawo pracy oparte jest na dialogu społecznym. Rozpatrując zatem powyższe zagadnienie, należy zwrócić uwagę, że zapotrzebowanie na nowe rozwiązania w zakresie prawa pracy powoduje, iż główna rola w jego kształtowaniu należy do partnerów społecznych, a więc w szczególności do związków zawodowych, a nie do państwa (Lewandowski 2003, s. 383).

Osobnej uwagi wymaga okoliczność, że klauzula społeczeństwa demokratycznego będzie odnosiła się w szczególności do akcji protestacyjnych mających charakter powszechny, 
ogólnopolski - tzw. strajku generalnego, który w świetle prawa polskiego jest strajkiem nielegalnym. W tym względzie należy zwrócić uwagę na aspekt międzynarodowego prawa pracy ${ }^{7}$ o czym poniżej.

\section{Regulacje prawa międzynarodowego dotyczące sporów zbiorowych}

Na wstępie należy zwrócić uwagę, że regulacje międzynarodowego publicznego prawa pracy w zakresie w ogóle akcji protestacyjnych załogi, w tym także prawa do strajku, są bardzo ogólne i niejasne. W szczególności konwencje Międzynarodowej Organizacji Pracy, a więc przygotowywane przez wyspecjalizowany do tego organ międzynarodowy, które winny regulować tę materię - w stosunku do innych aktów prawa międzynarodowego (paktów, rezolucji, deklaracji) - nie formułują wyraźnej podstawy prawa do strajku (Żołyński 2019b). Niemniej w zakresie już samych akcji protestacyjnych organy wykonawcze MOP zawierają stanowisko w zakresie sposobów czy możliwych postaci prowadzenia strajku. W tym też względzie należy wskazać na stanowisko Komitetu Wolności Związkowej odnośnie do prowadzenia strajków politycznych. Otóż uznano w nim, że strajki czysto polityczne nie mieszczą się, nie wchodzą w materię związaną z zasadą wolności związkowej (MBP 2012, nr 528, 529). Uznano jednakże, że tzw. strajki powszechne, ogólnokrajowe (generalne) są dopuszczalne, gdy jest to uzasadnione celami społeczno-gospodarczymi, a nie politycznymi. Z powyższego wynika, że w celu ochrony szeroko rozumianych praw pracowniczych strajki te mogą być przeprowadzone na przykład odnośnie do żądania podniesienia płacy minimalnej, respektowania układów zbiorowych pracy, zmiany polityki gospodarczej (np. obniżenia cen i zmniejszenia bezrobocia), gdyż wchodzą one w zakres normalnej działalności związkowej (MBP 2012, nr 543). W konsekwencji uznanie takiego strajku za nielegalny stanowiłoby poważne pogwałcenie wolności związkowej (MBP 2012, nr 541, 542). Pracownicy muszą bowiem mieć prawo do legalnego strajku,

7 Pod pojęciem „międzynarodowe publiczne prawo pracy” należy rozumieć zespół norm prawnych zawartych głównie w umowach międzynarodowych, które odnoszą się do zatrudnienia i stosunków pracy. Obejmuje ono także konwencje MOP oraz zalecenia i rezolucje organów MOP. Ponadto do międzynarodowego prawa pracy zaliczyć należy również regulacje zawarte w europejskim prawie pracy (Florek 2003; Świątkowski 2008). W doktrynie wyróżnia się także pojęcie „międzynarodowe prywatne prawo pracy", które ustanawia normy kolizyjne pozwalające na wskazanie prawa właściwego dla spraw (stanów faktycznych) powiązanych z prawem różnych państw i w tym sensie rozstrzyga sprzeczności, jakie zachodzą miedzy porządkami prawnymi różnych państw w przestrzeni. Inaczej ujmując, „międzynarodowe prywatne prawo pracy" dotyczy instytucji zawartych w unormowaniach umów międzynarodowych, w tym także aktach prawa unijnego (mającego właściwości prawa ponadnarodowego), a także unormowania krajowe wykorzystywane do regulowania kolizji norm indywidualnego prawa pracy. Świątkowski wprost definiuje to prawo uznając, że przedmiotem międzynarodowego prywatnego prawa pracy są normy pozwalające wybierać i stosować normy prawa pracy poszczególnych państw do oceny sytuacji prawnej podmiotów stosunków prawnych regulowanych przepisami prawa pracy (pracowników, pracodawców) oraz przepisami prawa zabezpieczenia społecznego (ubezpieczonych, ubezpieczających i ubezpieczycieli) (Świątkowski 2010, s. XXI; Sanetra 2009). 
którego celem jest krytyka polityki społecznej i gospodarczej państwa (Komitet... 1994, $\S 1865)$. Oznacza to tym samym, że instytucje MOP dopuszczają strajk o charakterze mieszanym (polityczno-społeczno-ekonomicznym) ${ }^{8}$. Już w Konstytucji Międzynarodowej Organizacji Pracy (Dz.U. 1948, nr 43, poz. 308) w preambule stwierdza się, że „pokój powszechny i trwały może być zbudowany jedynie na zasadach sprawiedliwości społecznej". Z powyższego zapisu wynika wywód logiczny prowadzący do wniosku, że sprawiedliwość społeczna może być osiągnięta wszelkimi, lecz legalnymi sposobami, w tym także przy wykorzystaniu prawa do oporu w postaci akcji protestacyjnych, u podstaw których leży niesprawiedliwość społeczna. Także Karta Narodów Zjednoczonych (Kocot, Wolfke 1976), zawarta w San Francisco dn. 26 czerwca 1945 r. (Dz.U. 1947, nr 23, poz. 90), w rozdz. IX „Międzynarodowa współpraca gospodarcza i społeczna” w art. 55 stwierdza, że w celu stabilizacji i dobrobytu ONZ popiera podniesienie stopy życiowej i pełne zatrudnienie, a także poszanowanie i przestrzeganie praw człowieka i podstawowych wolności dla wszystkich. Ponadto w art. 56 państwa członkowskie zobowiązały się współpracować zarówno indywidualnie, jak i zbiorowo w celu osiągnięcia celów wskazanych w art. 55. Skoro art. 55 odwołuje się między innymi do podniesienia stopy życiowej i nakazuje poszanowanie podstawowych wolności, to jedną z podstawowych wolności jest prawo do oporu przeciwko niesprawiedliwości w środowisku pracy, a zatem i pośrednio uznaje się prawo do strajku i innych akcji protestacyjnych. Z kolei w przytaczanej już Powszechnej deklaracji praw człowieka w art. 23 ust. 4 uznano, że: „Każdy człowiek ma prawo do tworzenia związków zawodowych i do przystępowania do związków zawodowych dla ochrony swych interesów". Przywołany artykuł ujmuje zatem zakres osób uprawnionych bardzo szeroko. Nie odnosi się do kategorii pracowników, a nawet do osób świadczących pracę, uznając wolność do zrzeszania się w związkach zawodowych za należną każdemu człowiekowi. Organizacje związkowe mają być zatem powołane do rzeczywistej ochrony interesów ich członków, a ponadto w świetle przepisów deklaracji należy nie tylko zapewnić swobodę w zakresie zrzeszania się w związki zawodowe, ale także nadać im uprawnienia, które pozwolą na rzeczywistą ochronę zrzeszonych w nich ludzi (Grygiel-Kaleta 2012, s. 282; 2015). Stąd należy wywodzić, że są uprawnione do prowadzenia akcji protestacyjnych w imieniu zrzeszonych w nich członków w celu ochrony ich praw i interesów. Powyższe postanowienia deklaracji dotyczące szeroko pojmowanej sfery prawa pracy stanowią wyraźne rozwinięcie i de facto doprecyzowanie art. 2 deklaracji, który nie pozostawia absolutnie żadnej wątpliwości co do charakteru praw człowieka. $\mathrm{W}$ art. 2 wyraźnie zadekretowano podstawowe wartości cywilizacyjne. Stwierdzono mianowicie, że:

Każdy człowiek posiada wszystkie prawa i wolności zawarte w niniejszej Deklaracji bez względu na jakiekolwiek różnice rasy, koloru, płci, języka, wyznania, poglądów politycznych i innych, narodowości, pochodzenia społecznego, majątku, urodzenia lub jakiegokolwiek innego stanu.

${ }^{8}$ Strajk generalny inaczej określany strajkiem powszechnym - strajk obejmujący cały kraj lub przynajmniej wszystkie ważniejsze jego ośrodki przemysłowe. 
W przedmiotowych artykułach niezmiernie ważne jest użycie dwóch określeń: „każdy”, a zatem wszyscy ludzie mają prawo do tworzenia i przystępowania generalnie bez ograniczeń do związków zawodowych, oraz „wszystkie prawa i wolności”, a zatem i prawo do oporu przeciwko niesprawiedliwości społecznej.

\section{Zakończenie}

Klauzula społeczeństwa demokratycznego jest wyrazem nowoczesnego podejścia do materii rozwiązywania sporów zbiorowych w środowisku pracy, a także rozwiązywania ważnych lub nabrzmiałych kwestii społecznych, socjalnych, gospodarczych czy nawet politycznych w państwie. Jest wyrazem zachowania godności człowieka, przy uwzględnieniu istotnych interesów państwa, jako wspólnoty ludzkiej. Jest jednocześnie wyrazem sumienia; troski o miejsca pracy, a zatem o podstawy ekonomiczne społeczeństwa. Stąd jest wyrazem rozsądku i przyzwoitości.

W aspekcie teoretycznym klauzulę tę można ustalać zarówno na podstawie regulacji zawartych $\mathrm{w}$ aktach międzynarodowego prawa publicznego, regulacjach krajowych, regulacjach autonomicznego prawa pracy, jak też bazując na przyjętym systemie aksjologiczno-filozoficznym oraz poglądach doktrynalnych na istotę państwa i prawa.

\section{Bibliografia}

Biśta I.J. (2010) Zasada poszanowania godności człowieka i jej wpływ na interpretację konstytucyjnego uregulowania praw i wolności jednostki [w:] M. Jabłoński (red.), Wolności i prawa jednostki w Konstytucji RP, t. 1: Idee i zasady przewodnie konstytucyjnej regulacji wolności i praw jednostki $w R P$, Warszawa.

Complak K. (2006) Zasada ochrony godności człowieka normatywnym nakazem obowiązującym pracodawców i organy stosujące prawo [w:] L. Wiśniewski (red.), Wolności i prawa jednostki oraz ich gwarancje $w$ praktyce, Warszawa.

Dörre-Nowak D. (1999-2000) Obowiązek pracodawcy szanowania godności i innych dóbr osobistych pracownika oraz konsekwencje jego naruszenia, „Studia z Zakresu Prawa Pracy i Polityki Społecznej”, s. 223-227.

Dörre-Nowak D. (2004) Monitoring w miejscu pracy a prawo do prywatności, „Praca i Zabezpieczenie Społeczne", nr 9, s. 8-14.

Dörre-Nowak D. (2005) Ochrona godności i innych dóbr osobistych pracownika, Warszawa.

Dörre-Nowak D. (2006) Zadośćuczynienie pieniężne za doznana krzywdę od pracodawcy dla pracownika, u którego mobbing wywołał rozstrój zdrowia, „Studia z Zakresu Prawa Pracy i Polityki Społecznej", s. 43-50.

Działocha K. (2010) Idee przewodnie wolności i praw jednostki w procesie uchwalania Konstytucji $R P$ [w:] M. Jabłoński (red.), Wolności i prawa jednostki w Konstytucji RP, t. 1: Idee i zasady przewodnie konstytucyjnej regulacji wolności i praw jednostki w RP, Warszawa. 
Florek L. (2003) Europejskie prawo pracy, Warszawa.

Grygiel-Kaleta Z. (2012) Wolność zrzeszania się w związki zawodowe w aktach prawa międzynarodowego, „Roczniki Administracji i Prawa”, rok XII, s. 282.

Grygiel-Kaleta Z. (2015) Wolność zrzeszania się w związkach zawodowych, Warszawa.

Jabłoński M. (2002) Rozważania na temat znaczenia pojęcia godności człowieka w polskim porządku konstytucyjnym [w:] B. Banaszek, A. Preisner (red.), Prawa i wolności obywatelskie w Konstytucji RP, Warszawa.

Jedlecka W. (2013) Obywatelstwo krajowe i UE - kwestia ochrony wolności i praw podstawowych [w:] A. Bator i in. (red.), Współczesne koncepcje ochrony wolności i praw podstawowych, Wrocław.

Kocot K., Wolfke K. (oprac.) (1976) Wybór dokumentów do nauki prawa międzynarodowego, Wrocław-Warszawa.

Komitet Ekspertów do Spraw Stosowania Konwencji i Zaleceń MOP [Committee of Experts on the Application of Conventions and Recommendations] (1994) General Survey.

Lewandowski H. (2003) Wplyw prawa wspólnotowego (Unii Europejskiej) na prawo wewnętrzne. Przykład Francji i Polski, Warszawa.

Machaj M., Szymaniec P., Bojek E. (red.) (2007) „Studia Erasmiana Wratislaviensia. Wrocławskie Studia Erazmiańskie. Zeszyt naukowy studentów, doktorantów i pracowników Uniwersytetu Wrocławskiego", t. 1.

Machnikowska A. (2004) Prawo jako kontrakt społeczny [w:] Z. Brodecki (red.), Zatrudnienie i ochrona socjalna, Warszawa, s. 99 i n.

Maniewska E. (2007) Indywidualne a zbiorowe prawo pracowników do informacji [w:] L. Florek (red.), Indywidualne a zbiorowe prawo pracy, Warszawa.

Masewicz W. (1993) Rokowania oraz spory zbiorowe pracy, Warszawa („Biblioteczka Pracownicza”, nr 26).

Masewicz W. (1994) Zatarg zbiorowy pracy, Bydgoszcz („Biblioteczka Służby Pracowniczej”, z. 75).

Międzynarodowe Biuro Pracy w Genewie (MBP) (2012) Wolność związkowa. Przegląd podjętych decyzji i wprowadzonych zasad przez Komitet Wolności Związkowych Rady Administracyjnej $M B P$, Gdańsk.

Oniszczuk J. (2010) Charakterystyka podstawowych zasad katalogu wolności i praw jednostki [w:] K.W. Baran (red.), Zarys systemu prawa pracy, t. 1: Część ogólna prawa pracy, Warszawa, s. 299.

Pettke P. (2014) Kilka uwag o dialogu zakładowym w przedmiocie BHP [w:] J. Stelin (red.), Zakładowy dialog społeczny, Warszawa.

Sadowski M. (2007) Godność człowieka - aksjologiczna podstawa państwa prawa, „Studia Erasmiana Wratislaviensia. Wrocławskie Studia Erazmiańskie”, s. 8-27.

Sanetra W. (2009) W stronę kolizyjnego międzynarodowego prawa pracy, „Praca i Zabezpieczenie Społeczne", nr 7, s. 2-10

Sękara M. (2008) Wolność zrzeszania się w związkach zawodowych pracowników administracji publicznej w świetle prawa międzynarodowego, „Studia z Zakresu Prawa Pracy i Polityki Społecznej", s. 49-50.

Sobczyk A. (2014) Prawo i człowiek pracujący - między ochrona godności a równości [w:] M. Skąpski, K. Ślebzak (red.), Aksjologiczne podstawy prawa pracy i ubezpieczeń społecznych, Poznań, 2014, s. 56. 
Szewczyk H. (2007) Ochrona dóbr osobistych w zatrudnieniu, Warszawa.

Świątkowski A.M. (2008) Międzynarodowe publiczne prawo pracy, vol. 1 i 2, Warszawa („Międzynarodowe Prawo Pracy", t. 1).

Świątkowski A.M. (2010) Międzynarodowe prywatne prawo pracy, Warszawa („Międzynarodowe Prawo Pracy", t. 2).

Świątkowski A.M. (2011) Ochrona prywatności w stosunkach pracy a prawo pracodawcy kontrolowania sposobów korzystania przez pracowników z zakładowych urządzeń elektronicznej komunikacji [w:] Z. Kubot, T. Kuczyński (red.), Z zagadnień prawa pracy i prawa socjalnego. Ksiega jubileuszowa Profesora Herberta Szurgacza, Wrocław.

Wiśniewski M. (2001) Kategoria godności osoby ludzkiej [w:] T. Jasudowicz (red.), Polska wobec europejskich standardów praw człowieka, Toruń, s. 39 i n.

Wujczyk M. (2012) Prawo pracownika do ochrony prywatności, Warszawa.

Zubik M. (red.) (2008) Wybór dokumentów prawa międzynarodowego dotyczacych praw człowieka, Warszawa („Księga Jubileuszowa Rzecznika Praw Obywatelskich”, t. 2).

Żołyński J. (2012) Zasada ekwiwalentności żądań i racjonalności ekonomicznej w sporze zbiorowym, „Monitor Prawa Pracy”, nr 8, s. 404-409.

Żołyński J. (2013a) Porozumienia kończące spór zbiorowy jako „swoiste” źródła prawa pracy, „Studia z Zakresu Prawa Pracy i Polityki Społecznej”, s. 432-454.

Żołyński J. (2013b) Strajk i inne rodzaje akcji protestacyjnych jako metody rozwiązywania sporów zbiorowych, Warszawa.

Żołyński J. (2016) Aksjologiczne, normatywne i społeczne podstawy prawa rozwiązywania sporów zbiorowych pracy, Gdańsk.

Żołyński J. (2018) RODO. Prawo do zapomnienia w sferze zatrudnienia, Warszawa.

Żołyński J. (2019a) Pojęcie międzynarodowego prawa pracy [w:] K.W. Baran (red.), System prawa pracy, t. 9, Warszawa [w druku].

Żołyński J. (2019b) Prawo do akcji protestacyjnej pracowników w świetle międzynarodowego prawa pracy. Mediacja i arbitraż [w:] K.W. Baran (red.), System prawa pracy, t. 9, Warszawa [w druku].

\section{Orzecznictwo}

Wyrok TK z 25 czerwca 2002 r., K 45/01, Dz.U. 2002, poz. 923.

Wyrok TK z 6 czerwca 2018 r., K 53/16, Dz.U. 2018, poz. 1149. 